\title{
Viewpoints
}

\section{The wounded healer during COVID-19: unraveling the violence against healthcare workers in Nepal}

\author{
Biplov Adhikari ${ }^{1}$, Roshan Subedi ${ }^{2}$, Rahul Kumar Thakur ${ }^{1}$, Preeti Shakya ${ }^{3}$ \\ ${ }^{1}$ BP Koirala Institute of Health Sciences, Dharan, Nepal, ${ }^{2}$ Institute of Medicine, Kathmandu, Nepal, ${ }^{3}$ Janaki Medical College, Janakpur, Nepal \\ Keywords: manpower, violence, nepal, policy \\ https://doi.org/10.52872/001c.26102
}

\section{Journal of Global Health Economics and Policy}

Vol. 1, 2021

\begin{abstract}
On $27^{\text {th }}$ May 2021, a nurse was working in the intensive care unit (ICU) at Bheri Hospital, Nepal when she was startled by a commotion. A hand grabbed her neck and choked her just as she looked behind. "She's the one responsible," said the perpetrator, whose brother had succumbed to the coronavirus disease (COVID-19), as his henchmen thrashed other staff on duty. Luckily a relative of another patient rescued the nurse from the vice of the attacker. The staff fled to the duty room. Huddled in the duty room, they wailed for their safety as the perpetrators banged at the door. They then ran into the toilet inside the duty room just as the duty room's door was broken open. As the door of the toilet could not keep them from the offenders, three nurses and a doctor jumped off the second floor, fearing for their lives. Fortunately, they landed on the sand and ran to safety. Two patients died because of lack of care amidst the chaos. ${ }^{1,2}$
\end{abstract}

This bizarre incident is just one of the many incidents of workplace violence (WPV) against healthcare workers that have occurred in Nepal. Just a week before, a healthcare worker (HCW) was beaten in the emergency department of a teaching hospital in Biratnagar. A patient, who was a doctor by profession, succumbed to his illness as the on-duty HCWs had to flee for their lives. ${ }^{1}$

In both instances, it was the enraged relatives of the patients who resorted to violence. They took it upon themselves to punish the HCWs-who have been dealing with overwhelming patient loads, especially during the COVID-19 pandemic. Although the studies to gauge the burden of WPV against HCWs in Nepal are inadequate, many have reported facing such incidents, more so in recent years. A study in India found $77.3 \%$ of doctors had ever faced some form of WPV, and several such incidents were reported during the pandemic. An ordinance from the Government of India recognized all acts of violence against HCWs confronting the pandemic as "cognizable and nonbailable offenses".3,4

Nepal, a lower-middle income country, has limited health resources, which the pandemic has stretched severely. According to the International Labor Organization (ILO), there are 0.67 doctors and nurses per 1000 people in Nepal, ${ }^{5}$ while the World Health Organization (WHO) recommended ratio is 2.3 per 1000 individuals. ${ }^{6}$ During demanding times like the pandemic, this dearth of HCWs can deprive patients of timely care.

Health literacy in Nepal is poor. The lay public does not understand the limitations of modern medicine. The pa- tient parties have expectations, sometimes unreasonable ones, despite the poor prognosis. Due to the poor penetration of health insurance patients have to bear all the costs of their treatment, which can be exorbitant. People from rural parts of the country who travel great distances to reach hospitals, often arriving too late or with incurable illnesses, find themselves angry and disappointed when their illnesses worsen. Expectation and frustration drive them to resort to violence.

The media too has been adding fuel to the fire. Misleading and biased news where HCWs are falsely accused of "harming" or "killing" a patient often become viral across social media platforms. The public does little to find out the truth. These biased media reports may further contribute to the general public's distrust toward HCWs and institutions, and thus aggravate the situation.

In the lack of clear laws enacted to protect healthcare workers from WPV, the perpetrators have also enjoyed impunity. Repeatedly, acts of violence against healthcare workers have been silenced or gone unreported. In the past, following an incident of WPV, the HCWs revolt, the government assures them of "addressing" the violence, the HCWs go back to their duties, and the lawmakers fail to deliver. One of the major demands - "Jail without Bail" has never been realized as it did not find itself in the priority of the bills enacted by the government.

These frequent acts of violence against HCWs can have a detrimental effect on their physical and psychological health and morale over time. The cumulative effects of these incidents can further lead to burnout in the field eventually driving away HCWs from their profession. ${ }^{7}$ This can further reduce the already scarce healthcare workforce and make it harder to meet patients' demands.

Prompt actions must be taken to punish the perpetrators and ensure the safety of all HCWs-through active lobbying by the concerned authorities. Techniques for clear communication, violence anticipation, and conflict resolution should be integrated early into the medical curriculum. More research and surveillance studies need to be employed to further understand the scope of this problem and tailor appropriate interventions. Failure to do so will only compromise the quality of care and put the whole healthcare provision at risk. 


\section{ACKNOWLEDGEMENTS}

None.

\section{ETHICS APPROVAL}

None sought.

\section{FUNDING}

None.

\section{AUTHOR CONTRIBUTIONS}

BA and RS conceived the study, designed the study and drafted the manuscript. RKT and PS drafted and revised the manuscript. All the authors read and approved the final manuscript.

\section{COMPETING INTERESTS}

The authors completed the ICMJE Unified Competing Interest form at (available upon request from the corresponding author), and declare no conflicts of interest.

\section{CORRESPONDENCE:}

Roshan Subedi, Institute of Medicine, Maharajgunj, Kathmandu, Nepal Roshansubedi123@gmail.com

Submitted: July 21, 2021 CET, Accepted: July 25, 2021 CET 


\section{REFERENCES}

1. Patrika N. One of the top news portal in Nepal, Trusted news portal of Nepal. https://nayapatrikadail y.com/nayapatrika/2021-05-28. Accessed May 29, 2021.

2. The Kathamandu Post. Health workers protest attack on medical personnel at Bheri Hospital.http s://kathmandupost.com/province-no-5/2021/05/29/h ealth-workers-protest-attack-on-medical-personnelat-bheri-hospital. Accessed May 29, 2021.

3. Kaur A, Ahamed F, Sengupta P, Majhi J, Ghosh T. Pattern of workplace violence against doctors practising modern medicine and the subsequent impact on patient care, in India. Joe W, ed. PLoS ONE. 2020;15(9):e0239193. doi:10.1371/journal.pone.0239 193
4. Kuppuswamy G, Warrier U. COVID-19 and Violence against doctors - Why a law is needed? J Family Med Prim Care. 2021;10(1):35-40. doi:10.4103/ifmpc.jfmp c 91220

5. Human Resources for Health Nepal Country Profile. $\underline{\mathrm{h}}$ ttp://www.nhssp.org.np/NHSSP_Archives/human_res ources/HRH_Nepal_profile_august2013.pdf. Accessed May 28, 2021.

6. WHO. Achieving the health-related MDGs. It takes a workforce! WHO. http://www.who.int/hrh/workforc e_mdgs/en/. Published 2018. Accessed May 28, 2021.

7. Hacer TY, Aygun A. Burnout in physicians who are exposed to workplace violence. Journal of Forensic and Legal Medicine. 2020;69:101874. doi:10.1016/j.jflm.20 $\underline{19.101874}$ 